\title{
LAND ASSEMBLY FOR HOUSING DEVELOPMENTS
}

\author{
Colrman WOOdBurY*
}

Although the tangible results of the present interest in housing have been slight, a few facts are beginning to emerge from the clouds of discussion and opinion. One of these facts is that housing developments, if they are to have any reasonable chance of success, particularly in blighted districts, should be planned on a large scale. Regardless of the types of houses to be built, unless a large area of land is included, the project can never be more than a qualified success and runs the risk of being a complete failure.

Support for this opinion comes in the main from two classes of people. Those who think of housing as the developing of economical and attractive residential districts demand large land areas in order that the site planners and architects may provide not only pleasant settings and surroundings for the houses but also the most usable spaces for recreation, schools, and other healthy social activities. They point out that developments on a large scale not only give greater amenities but also make possible considerable savings, in comparison with the old-style, lot-by-lot building, in construction and other development costs. For example, heavy traffic through the residential district can be avoided almost entirely with consequent increase in safety and in the quiet and pleasantness of the district. On the other hand, considerable expense can be saved in eliminating some nearly useless minor streets and in finishing the streets that are needed with pavement designed to accommodate only light local traffic.

Not only the housing planners but most of the property owners in blighted districts now recognize the necessity for projects covering a large area. Each owner sees that any attempt to improve his property alone is almost sure to fail unless it is supported by a program for the reclamation of the entire neighborhood. Scattered new buildings throughout a blighted and deteriorated section, no matter how well designed and constructed they may be, would soon be reduced to the level of their surroundings. This seems almost a self-evident statement, but in nearly every large city it can be supported by the actual experiences of some unduly optimistic and misguided property holders.

- Ph.D., Northwestern. Secretary of the Illinois State Housing Board, Associate Director of the National Association of Housing Officials, consultant to the Housing Division of the Public Works Administration. Formerly of the Institute for Economic Research and Assistant Professor of Economcs at Northwestern University. 
In some ways a blighted urban district is analogous to a swampy or an arid agricultural section. In both cases, to be of greatest use, the land requires a major improvement. The improvement cannot be carried out until some way is found of applying it on a large scale. Under most circumstances, one owner cannot successfully drain or irrigate his land, and one urban property holder cannot make headway against the blight that grips his district.

\section{The Established Technique of Land Assembly}

After the housing reformers and the property owners had recognized these facts, they turned to methods of bringing sizeable areas under single ownership or control. They found, of course, a procedure more or less familiar to real estate men, to the land departments of public utility companies and other corporations requiring a large amount of urban property, and to the corresponding divisions of municipal corporations. Briefly, this method consists of quietly securing options on as much of the area to be acquired as possible, often in the name of different persons and of dummy corporations, and buying the remainder at high prices, or, in the case of public corporations, exercising eminent domain in the manner prescribed by state law. Although remarkable ingenuity has been used by some specialists in this operation, a disturbingly large proportion of land assembly jobs have resulted in a very high price for the last parcels secured, or in slow and costly condemnation proceedings.

This procedure had been tried for housing developments prior to the recent popular interest in the subject. The results were as discouraging as might have been anticipated. The housing developers ran into all of the difficulties that had bedevilled others who had sought to secure large tracts of city land, "hold-outs," parcels without clear titles, and owners with strong sentimental attachments to their properties. However, one significant difference should be noted. If the land assembler is a private corporation or even a public body such as a park district, it usually can afford to pay an exorbitant price for some of the land it needs without too serious consequences. On the other hand, if the development is really low-cost housing, the margin of safety if costs must be so low that buying the property of a few "hold. outs," whether they be speculators or bona fide property owners with a strong attach. ment to their particular holdings, may very likely wreck the entire development. This again is a matter of experience as well as of reasonable expectation. Several carefully planned housing developments have been doomed before a single spadeful of earth has been turned or a single brick laid. The danger of being caught in this predicament probably has discouraged private capital from going into low-cost housing construction as 'much as any other one fact.

\section{Land Assembly Powers Under State Housing Laws}

During the latter part of 1932 and the early part of 1933 , limited dividend housing corporations under public control carried the hopes of most of those who wished to 
see housing construction become a major part of the recovery program. In drafting the laws that made possible these corporations, the facts concerning land assembly, which have been sketched above, were given some consideration. As a result, of fifteen state laws dealing with limited dividend housing corporations, eleven give the corporations some form of eminent domain to aid them in assembling land.

In those distant days, no feature of the proposed legislation seemed more advanced or radical, depending on the critic, than these provisions. Today, however, it is difficult not to admit that the eminent domain powers given by these laws, even when they are extended to housing authorities or other public bodies, are insufficient tools to deal conclusively with the difficulties of land assembly. Their shortcomings can be discussed conveniently under two headings: $(x)$ the cumbersomeness of the procedure required in most states; and (2) the confusion in rulings on the admissibility of evidence on land value.

\section{Procedure in Eminent Domain}

The question of housing as a public use is discussed briefly later in this article. Certainly those who see housing as a major economic activity of the next generation will breathe more easily if and when a few high state courts and the United States Supreme Court clearly recognize housing as a public use. As long, however, as the present condemnation procedure is required by the statutes of many states, housing developments will go ahead very slowly unless ways and means of avoiding condemnation in state courts can be found.

It is quite impossible to outline here the procedure required in all of the states in which new housing construction is a definite possibility. One of the worst features of many state laws, at least to the non-legal mind, is requiring an inexpert jury to listen to an almost endless amount of ex parte testimony on value, with few if any appraisals from an even moderately disinterested source. ${ }^{1}$ Too often, as a result, the proceedings drag on for weeks ${ }^{2}$ and the bewildered jurymen strike a rough average among the widely divergent appraisals given by so-called experts. This valuation often is very poor. The jury, knowing little of land values, often is impressed unduly by the reputation or manner of one or two of the witnesses. The confusion is increased by the length of the proceedings and the haggling of counsel over what is and what is not evidence of value. A few decades ago the procedure may have been satisfactory, but today very few people would contend that it is a method of securing quickly and economically the rather technical facts indicating values of city land.

The following outline of procedure in eminent domain cases was drafted during the earlier discussions of this power in housing development. ${ }^{3}$ Although by no

\footnotetext{
${ }^{1}$ Unfortunately, jury trial is guarantecd in such proceedings by the constitutions of many states.

In Massachusetts and some other states condemnation is by administrative order, with compensation finally determined by action following the taking. See Nickors, EMINENT Domain (2 ed. I917) c. xxi.

'By the author of this article. Approved and printed as an appendix to the Report of the Committee on Large Scale Operation, President's Conference on Home Building and Home Ownership. 3 President's Conference, Proceedings (r932).
} 
means exhaustive, it does present a procedure that is similar to that now in use in some states and deserves careful consideration.

r. Condemnation procedure should be conducted entirely separately from the fixing of local or benefit assessments.

2. Valuations should be set by a commission of three, selected by the court from a list of specially qualified persons appointed by all the judges in each city with jurisdiction over condemnation cases.

3. A time limit should be set by the court on the findings of the commission and should be extended only on application to the court by the commission.

4. All hearings before the commission should be public, with full public records kcpt. Both parties should be permitted to introduce such evidence as to valuation as might fall within the scope of the items entering into valuation as hereinafter set forth, ${ }^{4}$ and the commission should have power to examine any and all witnesses and to direct the presentation of additional permissible evidence where the commission considers it desirable.

5. Appeal by either party from the findings of the commission to a specially designated court should be provided.

6. The plaintiff in the condemnation suit should be permitted, after the award is made by the commission, to proceed at once to possess the property, provided he make payment to the court of such sums as have been awarded by the commission.

This procedure undoubtedly is an improvement on that now required in many states. It is based on the belief that the protection of the property owners lies not in an involved and tiresome procedure but in the ability and disinterestedness of those who appraise his property. Moreover, when housing is being urged as a part of a program to give employment and to stimulate economic recovery, a strong case can be made for allowing the agency seeking the land to take and enter upon it, upon posting of proper indemnity, even before the price of the property has been determined. 5 This action of entry might be given within the discretion of the court. The çourt also might decide the amount to be posted by the taker; or the bond might be set at an amount equal to the assessed valuation of the property or some proportion or percentage of assessed value.

At the present time, one of the most expeditious procedures is that given to the United States for acquiring land for federal public purposes. ${ }^{\circ}$ Presumably this procedure can be used in acquiring land for housing construction to be carried on by the Public Works Emergency Housing Corporation. It consists, broadly, of filing in a federal court upon or at any time after the filing of the petition in condemnation a "declaration of taking" setting forth the authority under which and the use for which the lands are to be taken, a description of the lands and a plat of them, and a statement of the sum estimated by the taker to be just compensation for the property. Upon the filing of this declaration and the depositing of the monies for

${ }^{4}$ See p. 219 , infra.

${ }^{8}$ See, c.g. Ohio Housing Authority Law, Ohio Laws 1933, 1st Spec. Sess., H. B. 19; New York Condemnation Law, N. Y. Cons. Laws (Cahill, r930) c. 9, \$24, and New York' Conscrvation Law, ibid. c. 10, 5559, 777 (8). See also Nichors, op. cit. supra note 2, c. xxi.

- 46 STAT. I42I (193I), 40 U. S. C. A. (Supp.) \$258a. 
payment, title to the lands vests in the United States and the former owners have a right to just compensation for them. The court has the power to fix the time and the terms for surrendering possession of the property to the government and may pay over to the former owners any part or all of the amount deposited by the taker at such times as the court may think wise.

This federal procedure seems admirably suited to prompt and vigorous action. If it is not copied in some form into more state laws, in the near future most of the land acquisition for housing purposes probably will be done by federal agencies of one kind or another. Assuming a reasonable exercise of discretion by the federal courts, the property owners' rights to fair cash compensation would seem amply protected.

Aside from this statute and others ${ }^{7}$ designed to facilitate prompt entry upon land to be condemned by federal authorities, there is no special federal condemnation procedure. Instead it is expressly provided by statute ${ }^{8}$ that federal condemnation procedure should conform as nearly as may be practicable to state law, and the federal government is thereby saddled with the deficiencies so common among state condemnation statutes. To remedy this situation, a bill prescribing the procedure in condemnation cases instituted by the Attorney-General of the United States is now pending in Congress. ${ }^{\circ}$

\section{Evidences of Land Value}

Courts of different states are far from agreement as to the facts that are admissible as evidence of property value in eminent domain cases. A complete catalogue of these differences and an analysis of them is quite beyond the scope of this paper. Two questions, however, should be discussed briefly. Should tax assessments be admitted as evidence of land value? Should prices at which options have been given or voluntary sales made by neighboring property owners to the condemner be considered in determining value?

Many cities' tax assessments probably are an accurate index of value, particularly for comparing the level of values in different sections of the city. They should be useful for estimating the value of the property to be taken by comparison with other

${ }^{7}$ The Emergency Relief and Construction Act of 1932, c. 520, $\$ 305,47$ Stat. 722, 40 U. S. C. A. (Supp.) $\$ 258 \mathrm{a}$ (note), provided a still more expeditious procedure based on the above statute. It has never actually been employed, however. The Rivers and Harbors Act of 1918, 40 STAT. 911, 33 U. S. C. A. \$594, authorizes the Secretary of War to take "immediate possession" of land upon the filing of the condemnation petition, provided the court finds that adequate security exists for the payment of compensation, by appropriation or by deposit or otherwise. This Act has been utilized successfully in flood control work where the condemnation of large areas was involved.

${ }_{25}$ StAT. 357 (1888), 40 U. S. C. A. $\$ 258$.

' S. 2647, 73rd Cong., and Sess. (I934). At the time of writing, this bill had passed the Senate. It provides for the appointment of commissioners to determine awards but, unfortunately, permits any party to demand a common-law jury. The Supreme Court has never conclusively determined whether the Seventh Amendment necessitates a trial by jury in condemnation cases, but there is little reason to suppose that a jury will be held requisite. Sce Blair, Federal Condennation Proceedings and the Seventh Amendment (I927) 41 HARv. L. REv. 29; Hines, Does the Seventh Amendment . . . Require Jury Trials in all Condenmation Proceedings? (1925) II VA. L. REv. 505. The bill is silent on rules of evidence as to value in condemnation cases. 
land for which recent sales figures are introduced as evidence. If a city's assessment system is inadequate or discriminatory, this fact could be established with sufficient force to discount the assessed values in the minds of the jury or of the commission charged with valuing the property. Despite the rulings in many states against tax assessments in eminent domain cases, it is not at all uncommon for one side or the other to have the tax assessor or someone from his office as an expert witness.

Another general rule on evidence of value that deserves reconsideration excludes options or sales of property made to the taker in the condemnation proceeding. Thus a public body acquiring a site may reach an agreement with seventy-five per cent or more of the property owners as to a fair price for the land, but cannot submit these figures as evidence of the value of the land of the comparatively few owners against whom condemnation suits have to be brought. Strangely enough, the reasonş given for excluding these facts as evidence are quite contradictory. Some courts believe that these figures on transfers or options are poor evidence of value because the body acquiring the property would be willing to pay considerably more than a fair cash value in order to avoid the delay and expense of a condemnation suit. The figures in question, therefore, are thought to be too high to be considered as evidence of fair market value. On the other hand, other decisions have excluded these figures on the ground that the property owner is at a disadvantage in bargaining with a public body that has powers of eminent domain and, therefore, would be willing to settle for a price somewhat below fair value.

No reasonable person would deny that both of these opinions correspond to possible situations in the negotiations between a purchaser and an owner. If, however, the voluntary seller and the agent of the purchaser were subject to cross-examination, it would seem that "agreements" in which one of these influences had been particularly strong might be excluded without ruling out entirely the figures of genuinely voluntary sales. Another possibility would be to allow these prices, to be introduced as evidence only if supporting testimony would show that both parties considered the exchange to have been made at a fair and reasonable price and without compulsion or undue influence.

The following statement of principles on evidence of property value in eminent domain proceedings is submitted for study and criticism. ${ }^{10}$ It assumes a qualified commission as the primary agency to which evidence of value would be presented. These commissioners, by the nature of their qualification, would have a more acute critical sense as to property values than would ordinary jurymen and might be expected to consider more varying evidence of value without being misled by the less important ones. Cértainly they could consider assessed values and voluntary transfers between the owner and the condemner without serious risk of giving undue

\footnotetext{
${ }^{20}$ These principles were presented in a report by the writer to the Committee on Large Scale Operations, President's Conference on Home Building and Home Ownership, which was approved and adopted. Sec 3 President's Conference, Proceedings (1932).
} 
weight to slip-shod assessments or to prices that were markedly effected by fear of or desire to avoid condemnation proceedings.

I. The following evidences or indications of value of the property taken should be considered by the commission whenever possible, and the report of the commission to the court should include a clear summary of the evidence submitted on each of the following points:

(a) Transfers of properties in the same areas as those under condemnation, which can be shown to be between willing buyers and willing sellers, including transfers made between private owners and the city or between private owners and the housing company for the same or similar purposes as that for which the condemnation action was begun.

(b) Assessed valuation for purposes of taxation and the stipulated ratio of assessed to true value for the preceding five years.

(c) The estimated gross and net incomes receivable from the most productive use to which the land may reasonably be put in the near future; the estimated length of time before such use could profitably be established; and the rate at which the net income should be capitalized taking account of all risks involved in establishing such a use. In cases in which the present use is not the most productive use, the value of the land alone, as indicated by this method, should not exceed the capitalized net income minus the total cost of constructing the building or buildings that would be required to make possible the most productive use.

2. In determining fair compensation for the property to be taken, no evidence should be admitted which reflects the probable influence of the proposed improvement on property values.

3. In no case should income receivable from uses contrary to the health or other laws of the municipality or state, or transfer prices based on the expectancy of such use, be admitted as evidence of land value.

4. Values of existing buildings should be determined by the cost of replacing the present structures minus an allowance for depreciation and obsolescence. Residential buildings declared by the municipal health department to be unfit for human habitation should be evaluated at their scrap value minus the cost of wrecking.

\section{Is Housing a Public Pukipose?}

In general, the state supreme courts have followed one of two lines in defining what is and what is not a public use. ${ }^{11}$ Those following the stricter construction have taken public use to mean use by, or at least the right of use by, all or a large part of the community. Thus the Illinois Supreme Court in the case of Gaylord $v$. Sanitary District said:

\footnotetext{
I2 In most industrial states the power of eminent domain has been granted by statute to a large number of uses. A fairly typical state in this respect is Illinois, which allows condemnation by cities and villages for water works and reservoirs, sewers, streets and alleys, levees and embankments, public coliseums, municipal convention halls, harbor structures and facilities, libraries and water courses. In addition, the more common public utilities enterprises (including railroads, electric light and power companies, gas companies, telephone companies), schools, and parks have this power. Other agencies that may exercise eminent domain include counties (for public buildings), canal companies, cemeteries, drainage districts, ferries, mills, mines, mosquito abatement districts, warehouses, roads, public and toll bridges. Although some of the agencies listed rarely use this power and some of them have not tested this right in court, such a list does raise some hope that soon low-cost housing may be recognized to be at least as public in character as, say, cemeteries or mills.
} 
To constitute a public use something more than a mere benefit to the public must flow from the contemplated improvement. The public must be to some extent entitled to use or enjoy the property, not as a mere favor or by permission of the owner, but by right. ${ }^{12}$

The supreme courts of another group of states, taking a somewhat broader view of public use, make it roughly synonymous with unmistakable public benefit or advantage. For example, in the case of State ex rel. Twin City Building and Investment Company $v$. Houghton, ${ }^{13}$ the court upheld a statute providing for the restriction of uses in a residential district and the compensation for the privilege "taken" by benefit assessments in property. This taking was deemed for public use even though, of course, it gave the public no physical use of the privilege taken and though only a limited portion of the public would be directly benefited.

This opinion also included an excellent statement of the attitude generally taken by courts in the more liberal definitions of public use. ${ }^{14}$ The Court said:

The notion of what is public use changes from time to time. Public use expands with the new needs created by the advance of civilization and the modern tendency of the people to crowd into large cities. Such a taking as here proposed could not possibly have been thought a taking for public use at the time of the adoption of our constitution when the state was practically a wilderness without a single city worthy of the name. The term public use is flexible and can not be limited to the public use known at the time of the forming of the constitution. 15

Housing as a public use apparently has not been passed upon by a high state court in an action brought in respect to eminent domain proceedings. Two state supreme courts, however, have passed in comparatively recent years on housing as a public purpose for which state funds were to be spent. Unfortunately, in neither of these cases was the question of slum and blighted area housing raised as clearly as it might be today.

The earlier decision was by the Supreme Judicial Court of Massachusetts in Igr2. It was an advisory opinion. ${ }^{18}$ A bill had been drafted to authorize the Homestead Commission of Massachusetts to purchase, develop, rent, manage, and sell residential real estate. The Court advised that this was not a public use for which public monies could be spent. ${ }^{17}$ It was clearly stated in the opinion, however, that if public money

${ }^{2}$ Gaylord v. Sanitary District, 204 Ill. 576, 584, 68 N. E. 522, 524 (r903).

13 144 Minn. I, 176 N. W. 159 (1920).

s Of course, this classification of state courts on the definition of public use is very general. In many states in which the courts have quite consistently followed one line of definition, it is possible to find opinions that seem to be decidedly "out of line." For a classification of state courts on this point, see Nichols, op. cit. supra note 2, $\$ 40$.

${ }^{25} \mathrm{r} 44$ Minn. at $16,176 \mathrm{~N}$. W. at $\mathrm{r} 6 \mathrm{r}$.

${ }^{21}$ In re Opinion of the Justices, 211 Mass. 624,98 N. E. 611 (1912).

${ }^{27}$ Largely as a result of this decision an amendment was made to the state constitution in 1915 . The amendment, Chapter 6, Article 43, reads as follows: "The general court shall have power to authorize the commonwealth to take land, to hold, improve, subdivide, build upon and sell the same, for the purpose of relieving congestion of population and providing homes for citizens: provided, however, that this amendment shall not be deemed to authorize the sale of such land or buildings at less than the cost." It was ratified on November $2,19 \times 5$, by a popular vote of 284,568 to 95,148 . 
could be spent for this purpose, eminent domain might also be exercised to achieve the ends set forth. In fact, the opinion dealt at some length with the possible difficulty of the Homestead Commission condemning the property of one free holder in order to turn it over to another person. The intent of the bill was quite clearly that the Commission would sell the properties sooner or later to their occupants and thus encourage home ownership.

One of the last paragraphs in this opinion gives an interesting sidelight on the housing thought of that day. The Court said:

It may be urged that the measure is aimed at mitigating the evils of overcrowded tenements and unhealthy slums. These evils are a proper subject for the exercise of the police power. Through the enactment of building ordinances, regulations and inspection as to housing and provisions for light and air lies a broad field for the suppression of mischiefs of this kind. ${ }^{18}$

With the experience that has accumulated during the last twenty years, it seems very doubtful that any high court of an industrial state could today make so naïve and optimistic a statement of the possibilities of housing improvement by way of building ordinances and other restrictive legislation. Certainly one of the key arguments in the case for housing as a public purpose is the fact that restrictive police power measures have not removed slums nor stopped blight. More active measures are needed and of those proposed the most likely at present seems to be the rebuilding of large areas into modern residential districts. Eminent domain is thought to be necessary to secure sufficiently large tracts to give this method a reasonable trial.

The second case on housing as a public use, Green $v$. Frazier, ${ }^{10}$ was decided by the Supreme Court of North Dakota shortly after the War. The statute in question was the Home Building Act, ${ }^{20}$ one of a series of statutes passed by the North Dakota legislature (in a program including two amendments to the constitution) giving the Industrial Commission of the state power to engage in several economic activities, including the marketing and storage of farm products, mortgage lending, and the building of low-cost homes. This act was attacked on several grounds, including the assertion that the building of homes was not a public purpose for which state funds properly could be spent. The Court held it valid, remarking that it best exemplified the "broad public policy" of these laws and constitutional amendments "intended to be beneficial to every citizen of the state as well as the state as such."21

The opinion dealt with so many issues that the housing question was not discussed in as much detail or in as firm a manner as one would wish. The Court gave considerable attention to the plight of tenants, particularly tenant farmers, and went at length into the benefits that would accrue to the state if it would encourage home ownership. This entire argument probably will be given relatively little attention in cases to be brought in the near future on housing as a public purpose. Whatever the merits of home ownership may be, very few of those most interested in large

\footnotetext{
${ }^{13} 2$ I I Mass. at 630, $98 \mathrm{~N}$. E. at 614 .

${ }^{21} 44$ N. D. 395,176 N. W. I: $(1920)$.
}

${ }^{20} \mathrm{~N}$. D. Laws, 1919, c. 150.

${ }^{21}+4$ N. D. at $422,176 \mathrm{~N}$. W. at $2 \pi$. 
scale housing developments believe that people of very low economic status should be encouraged at the present to invest a large proportion of their meagre savings in residential real estate.

The decision of the United States Supreme Court affirming the North Dakota Court's decision is discussed below. ${ }^{22}$

A more recent case that is often cited on this question is Simon $v . O^{\prime} T o o l e .{ }^{23}$ This is a decision of the Supreme Court of New Jersey that was affirmed later by the Court of Errors and Appeals. ${ }^{24}$ Strangely enough, no separate opinion was rendered by the higher state court although the decision of the court below was affirmed only by a vote of six to five.

As a matter of fact, in this opinion the Court did not pass on the question of whether housing is a public use. The city of Newark, in conformity with state laws passed in $1929^{25}$ had made an agreement with the Prudential Insurance Company whereby the insurance company agreed to secure title to as much of two city blocks as it could in a blighted area in Newark, and the city agreed to buy from the Prudential or, if necessary, to condemn from other property owners, a strip of land I40 feet wide running through the middle of these blocks for use as a park and playground.

Although the Court based its decision on the ground that the land was to be devoted to public parks and playgrounds, a well-established public use, it recognized that the major purpose' of both the state enabling legislation and the city's action was to make possible a housing development by taking a portion of the usual land cost from the shoulders of the developing company. Perhaps a court may yet be persuaded that in fact playgrounds and sanitary houses are integrated parts of any well-planned neighborhood.

In many ways, one of the most interesting cases on the question of public use, although it is not concerned directly with housing, is Dingley v. City of Boston.20 The Massachusetts court upheld a statute ${ }^{27}$ authorizing the city of Boston to condemn an area of low-lying land, of about sixteen acres in extent, from which sewage drained into Back Bay, for the purpose of raising the land sufficiently to enable the drainage of sewage into deep water and thereby remedy a condition which constituted a nuisance to the public health.

Property owners sought to enjoin the wrecking of buildings, contending in part that to condemn the fee in the land was an improper method of abating the nuisance. The Court, however, pointed out that the interests of the property owners would be very difficult of adjustment after the land had been raised and termed the plan of condemning of the fee "the most simple and equitable that could be adopted." Its decision was cited with approval by the United States Supreme Court in Stveet $v$. Rechel, ${ }^{28}$ a case arising out of the same improvement project.

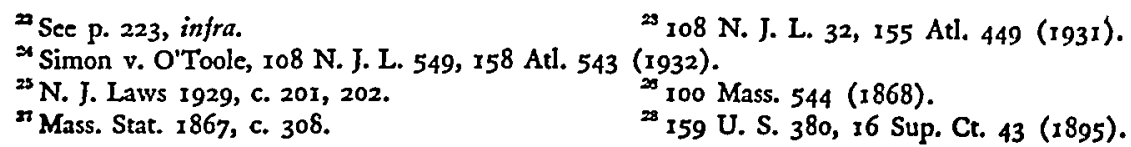


A rather close analogy can be drawn between this action of the city of Boston and the program outlined at the present time by various public bodies for the rehabilitation of blighted or slum areas. The chief difficulty would seem to be to establish clearly in the mind of the court the fact that blighted and deteriorating housing is quite as much a matter of public concern as a safe method of sewage disposal. If this can be done, the weight of these decisions ought certainly to be on the side of upholding housing as a public use.29

In all probability a case on the constitutionality of the taking will reach the United States Supreme Court in the near future, especially if condemnation of land for housing is undertaken under the federal statute described above. Here, as in most of the state courts, few, if any, decisions are directly in point. In affirming the North Dakota decision in Green v. Frazier, discussed above, ${ }^{30}$ the United States Supreme Court stated:

As we have said, the question for us to consider and determine is whether this system of legislation is violative of the Federal Constitution because it amounts to a taking of property without due process of law. The precise question herein involved, so far as we have been able to discover, has never been presented to this court. The nearest approach to it is found in Jones v. Portland, 245 U. S. 217 . . in which we held that an act of the state of Maine, authorizing cities or towns to establish and maintain wood, coal, and fuel yards for the purpose of selling these necessaries to the inhabitants of cities and towns, did not deprive taxpayers of due process of law within the meaning of the r 4 th Amendment. In that case we reiterated the attitude of this court towards state legislation, and repeated what had been said before, that what was or was not a public use was a question concerning which local authority, legislative and judicial, had especial means of securing information to enable them to form a judgment; and particularly, that the judgment of the highest court of the state, declaring a given use to be public in its nature, would be accepted by this court unless clearly unfounded. In that case the previous decisions of the court sus. taining this proposition were cited with approval, and a quotation was made from the opinion of the supreme court of Maine, justifying the legislation under the conditions prevailing in that state. We think the principle of that decision is applicable here. ${ }^{31}$

Although the Court here held housing construction to be a public purpose under the conditions existing at the time, three facts should be noted. In the first place, the Court did not pass on housing as a federal public purpose, as it will have to if a case is brought under federal statute. ${ }^{32}$ Secondly, the opinion stressed throughout the weight to be given to the opinions and findings of state legislatures and state courts. This consideration, of course, will not obtain in proceedings brought directly

20 The fact that these cases involved the treatment of a considerable tract of land is also worthy of note. The term, "zone condemnation," has sometimes been applied to this procedure to distinguish it from less extensive uses of eminent domain for rights of way or smaller land areas. It describes quite accurately what may be necessary in securing suitable sites for housing developments.

${ }^{20}$ See p. 221, supra.

${ }^{21}$ Green v. Frazier, 253 U. S. 233, 241, 40 Sup. Cr. 499, 502 (1920).

12 The question whether the federal government may constitutionally exercise its eminent domain powers for a purpose not within the scope of the powers expressly delegated to it by the Constitution is discussed in Seaks, A Note on the Power of the Federal Government to Condemn Land for Hoising, infra. p. 232. 
under federal statute. Finally, the action did not primarily concern eminent domain but was brought to prevent the use of public monies for what was alleged to be not a public purpose. ${ }^{33}$

Those who hope that the United States Supreme Court will uphold housing as a public use when the question is presented directly to it, can point to many dicta of the Court that indicate a friendliness toward extending the concept of public use, if the extension rests upon economic and social facts. In the case of Fallbrook Irrigation District v. Bradley ${ }^{34}$ the Court passed upon a California statute that authorized the formation of irrigation districts with power to levy assessments and to condemn or otherwise acquire land. The case was brought to resist the sale of land in default on assessment levies. The Court said:

While the consideration that the work of irrigation must be abandoned if the use of the water may not be held to be or constitute a public use is not to be regarded as conclusive in favor of such use, yet that fact is in this case a most important consideration. Millions of acres of land otherwise cultivatable must be left in their present arid and worthless condition, and an effectual obstacle will therefore remain in the way of the advance of a large portion of the State in material wealth and prosperity. To irrigate and thus to bring into possible cultivation these large masses of otherwise worthless lands would seem to be a public purpose and a matter of public interest, not confined to the landowners, or even to any one section of the State. The fact that the use of the water is limited to the landowner is not therefore a fatal objection to this legislation. It is not essential that the entire community or even any considerable portion thereof should directly enjoy or participate in any improvement in order to constitute a public use. ${ }^{35}$

The case of Rindge Co. et al. v. County of Los Angeles ${ }^{36}$ dealt with the condemnation of land for a highway running twenty miles through a private estate bordering the ocean. The branch road for which land was condemned was connected with the public highway system only at one end. It was primarily a pleasure drive. In upholding the condemnation action the Court said:

It is not essential that the entire community, nor even any considerable portion, should directly enjoy or participate in any improvement in order to constitute a public use. ... Public uses are not limited, in the modern view, to matters of mere business necessity and ordinary convenience, but may extend to matters of public health, recreation and enjoyment. . . And manifestly, in these days of general public travel in motor cars

\footnotetext{
23 The connection between the "public purpose" cases in federal courts involving taxation and those concerned with eminent domain was pointed out in the Court's opinion in Falibrook Irrigation District v. Bradley, 164 U. S. $112,158,17$ Sup. Ct. 56, 63 (1896). After remarking that the due process clause of the Fourtecnth Amendment, applying to state legislation, is not accompanied by any express restriction against the taking of property for any but a public use, as is contained in the Fifth Amentment, applying to fedcral legislation, the Court continucd:

"It is claimed, however, that the citizen is deprived of his property without due process of law, if it be taken by or under state authority for any other than a public use, either under the guise of taxation or by the assumption of the right of eminent domain. In that way the question whether private property has been taken for any other than a public use becomes material in this court, even where the taking is under the authority of the State instead of the Federal government."

"Supra note 33 .

25. ${ }_{4} 5_{4}$ U. S. at 161,17 Sup. Ct. at 64 .

^ 62 U. S. 700,43 Sup. Ct. 689 (1923).
} 
for health and recreation, such a highway as this, extending for more than twenty miles along the shores of the Pacific at the base of a range of mountains, must be regarded as a public use. ${ }^{37}$

In summary then-the determination of the courts on housing as a public use is yet to be made. The attitude of the Supreme Court on definitions of public use is decidedly encouraging to those who believe that eminent domain is a power essential to a vigorous housing program. The state supreme courts probably will divide on this question unless influenced by a strong opinion upholding housing as a federal public purpose. In cases before either state or federal courts, the need for large tracts of land in any well-planned housing development must be emphasized. The courts must have the chance to see the actual difficulties to be faced in attempting to assemble land for low-cost urban housing. This must be supplemented by facts on the failure of unaided private enterprise under modern urban conditions, with or without police power restrictions, to provide healthful, sanitary housing for the lower-income classes.

\section{First Steps in Assembbling the LAND}

Eminent domain seems to be an essential power in the rebuilding of blighted and slum districts. ${ }^{38}$ If housing is upheld as a public purpose and reasonably rapid procèdure in eminent domain can be established for housing authorities and other public and quasi-public agencies, a long step will have been taken toward a genuine attempt in city rebuilding. However, it would be a serious blunder to assume that securing the power of eminent domain is all that has to be done in assembling land for housing purposes. Assuming that the power has been granted and upheld, what are the other major problems that will have to be faced at once? ${ }^{39}$

"Ibid. at 707, 43 Sup. Ct. at 692 .

ss The writer has assumed throughout this article that public agencies of one kind or another will be in charge of the housing program in the near future at least. The inadequacies of limited dividend corporations under present circumstances have been clearly shown. For this reason, no attempt has been made to discuss here the various plans devised to attract, and if necessary compel, private land owners to pool their holdings in order that a reasonably large district can be repaired or reconstructed as a unit. The writer believes that some of these plans have considerable promise and should be given a trial. The housing that they will make possible, however, in most cases will be at higher rentals than can be provided by public bodies with the subsidy now available from the PWA.

This does not mean that these ideas may not have an important role in the future housing program in this country. This housing program certainly should include more than slum clearance. Thousands of families in the cities of this country do not live in slums nor in blighted areas but still have to occupy housing that is mediocre in every way and far below standards that reasonably can be expected from the present knowledge of community planning and construction. The writer, however, had to limit this article at some point and has preferred to try to focus the discussion on the problems that in the immediate future will face the agencies that will attempt low-cost housing. These agencies will be public bodies of one kind or another.

The chief exponents of these pooling schemes are Clarence Perry, The Rebuilding: of Blighted Areas, Regional Plan Association, New York City (1933), especially Part Two; Herbert U. Nelson, Executive Secretary of the National Association of Real Estate Boards (sce recent issues of the National Real Estate Joumal); Thomas S. Holden (see recent issues of the Architectural Record and Architectural Forum); and Henry K. Holsman, Rehabilitating Blighted Areas, Architcets Club of Chicago (1932). Sce also Nelson, supra p. 164 ; Blucher, infra p. 248.

INo attempt has been made in this article to go into the details of land assembly procedure except on those points that seem crucial in a program of assembly for housing. Questions of procedure, as for 
In the first place, the initial steps in land assembly in different communities must be determined with care. To assume that a start can be made in almost any fashion and that errors can be covered up later by eminent domain proceedings is very shortsighted. The public reaction to the entire housing program of a city may well be determined by the way in which land is assembled. In almost every case, at least in the immediate future, speed will be demanded in acquiring property. This speed should not be secured at the cost of a ruthless method that will arouse wide-spread public antagonism. At the same time, land costs must be kept as low as is possible. To achieve the finest balance among these and some minor considerations will be by no means an easy job.

The advice of nearly all experienced land assemblers is to start by securing options or conditional sales agreements from as many of the property owners as possible. This, as has been pointed out above, has been the traditional method. Its effectiveness at the present time, however, may be questioned seriously. The present market for land in blighted districts of cities is generally so very quiet and the probable purchasers are so few that within a few hours after any considerable number of land owners have been approached, they and their neighbors for some distance around will probably realize exactly what is being done. In some communities, moreover, a strong feeling exists that the government ought always to announce its plans before undertaking any enterprise involving large sums of money. This may be and probably is, in many cases, an indefensible opinion, but deference to it in some communities might easily outweigh the doubtful advantages of the method of quiet options.

In other cities, it will be necessary, in order to overcome opposition to a housing program, to engage in public debate and discussion through the press and otherwise for some time before actual work on a development can be begun. A variant of this will be the necessity of a wide-spread discussion of the areas to be undertaken either by a local housing authority or by a federal agency. These circumstances clearly rule out any effective taking of secret options. For the first few developments, at least, it may be possible "to play off one district against another"-to say quite frankly that housing developments are under consideration for two out of say six or eight possible areas and that it is the intention of the housing agency to start first in those areas in which good titles to the land can be secured most quickly and most cheaply. No one can foretell the possible results of this procedure in every city. It would seem to have a good chance of success at the present time, in some cities at least. It will not be very useful later, however, when the more reasonable program of the housing agencies will be to expand the developments that they will have begun.

Another advantage of a non-secret method is that it will allow the housing agency to mobilize the forces in the areas that wish to see the development go ahead. Obsti-

example, what kinds of instruments to use in voluntary negotiations -an option, a real estate contract, or a deposit agreement for placing a warranty deed in escrow-are important but can be decided readily by those who know the business custom and experience with the different devices in different cities. 
nate land holders in most blighted areas probably would be little influenced by widespread publicity in the big daily newspapers and other city-wide institutions. The little property owner probably would say that if a governmental agency backed by the rich and powerful in the community is anxious to have his property, it should pay his price. He may be more susceptible, however, to pressure from his neighboring property owners who have agreed to sell and have given an option or have a purchase agreement with the housing agency conditioned upon the agency securing similar agreements with all or a large proportion of the land owners in the neighborhood.

Another possible line of attack would be to institute condemnation proceedings at the outset against all of the property that is needed for the development. Probably in some communities this might be done with no intention of carrying through the action unless voluntary agreements could be reached with a large proportion of the land owners. The intention of the housing agency to purchase for a reasonable price could be announced at the same time that the eminent domain proceedings were begun. This method might have two advantages. It would indicate to the property owner that the housing agency was willing to meet him on a reasonable, voluntary sale but that it was also determined not to be held up by a few obstinate individuals. Probably a more substantial advantage would be shutting out "wash sales," faked mortgages, and other manoeuvers that might be made to build up evidence of higher land values.

Under some circumstances, of course, it may seem wise to go ahead with the condemnation proceedings against all of the properties and to pay the awards as they are made. Under the federal statute this might save time and be a direct and effective procedure. It does have the danger, however, of being made to seem to be high-handed and arbitrary.

Both of the programs calling for early filing of condemnation suits have in common one major advantage. If the preliminaries of the program have been shrewdly and cautiously carried out, the court action should shut out most of the professional speculators. The corollary of this is, of course, that the money paid for the land would go largely to bona fide property owners, many of whom may have held the property with little or no profit for many years. Some slum properties, of course, have been most profitable investments, but even in regard to them it would seem better that the payment should go to the propery owner than to some speculator whose only interest in the property is to secure some title or estate in it for which he will have to be paid by the public agency. Obviously this species of land shark can operate more successfully against the small, uninformed holder of an unprofitable property than against the large owner who over a period of years may have secured a high return on his investment. In any event, one of the chief objectives of the land assembly program should be to squeeze out the land speculator.

The issues raised above can not be answered in general terms. It is more than 
an excuse to avoid answering knotty problems to say that the method of procedure can be determined only in the light of all the circumstances attending the program in any city. Variations and combinations are, of course, possible. It may be desirable to follow different methods for the different areas that are to be taken in the large cities.

\section{Heavily Mortgaged Properties}

Another major problem, in many ways the most disquieting of all, is presented by the holder of heavily mortgaged properties that have to be acquired in the housing program. The unmortgaged land holder or the one with a conservative mortgage on his property presents no very grave difficulty. Land values have declined sharply in blighted districts in recent years and probably will decline even more in the future. The holder of unencumbered land who sells at the present time or whose land is condemned probably will lose something of his investment, particularly if he bought during the wild boom of the 20's; but, after all, nearly all investments have declined in value and by securing cash in place of title to land in a deteriorating district, he will be, and in many cases will recognize that he will be, better off.

The holder of heavily mortgaged properties, however, can not be disposed of so easily. It must be recognized, furthermore, that in many blighted districts he probably is in the majority. A recent study of the Lower East Side of New York showed that about ninety per cent of the properties were mortgaged. Undoubtedly many of the mortgages are based on the fantastic land values that have been assumed for years for that district. In Chicago, a study of two sizeable blighted areas has shown that from two-thirds to four-fifths of the properties are mortgaged and that in some sections the ratio of outstanding mortgage indebtedness to assessed value, or other measures of probable purchase price, is high. No one knows in how many casesbut it probably would be a considerable number-sales at present market value, whether induced by the financial condition of the land owner, by group pressure, or by eminent domain, would wipe out the equity in the property completely.

Of course, one may say that this is just one of the unfortunate results that attend any program of economic advance; that the automobile industry bankrupted the carriage manufacturers, etc., etc. The heavily mortgaged owner is in the same position as anyone else who holds property on a margin. He has taken the chance of large return on his actual investment and of an increment in the value of his holdings and must, therefore, be expected to shoulder the losses that come his way. Further, it may be argued with some force that his equity does not exist at the present time and that the only reason he does not realize this is the absence of market quotations on the particular kind of property in which he has invested. If a housing agency forces a sale in one way or another, the owner may blame the agency for his financial plight but, as a matter of fact, it did not cause his loss but only revealed it clearly to him. To the reply that his equity might be revived with a general increase in property values, it may be contended that the chances of a widespread revival of 
values in blighted and residential districts is so slight as to be negligible. From this line of argument it follows that the housing program should be driven ahead vigorously, that the hardships and losses that it entails will be much more than counterbalanced by the benefits and advantages that it will create.

On the other hand, it may be said that, financial technicalities ${ }^{40}$ aside, the land owner was only one of several people who put their money into the development of the district; that his judgment was not much worse than that of the mortgagees; and that in many cases the mortgagee has made no attempt to develop the district, whereas the land owner has tried, although the job has been quite beyond the means at his disposal. Again some of the land owners in the blighted districts are victims of the bally-hoo for home ownership that has been sponsored by influential groups, including, in some cases, government officials of considerable position. Furthermore, the federal government has tried in various ways to protect the owners of selected kinds of properties from feeling the full effects of the depreciation in property values (e.g. through the Home Owners Loan Corporation). Emphasizing these facts and opinions, it seems somewhat incongruous, not to say unfair, for a public housing agency to force considerable losses on some of the land owners in an area that is to be rebuilt. (On many properties, of course, mortgagees and other lien holders will suffer to some extent as well).

This argument will appeal strongly to some people, but not to others. Without going into a lengthy discussion of the questions raised, it may be said that an attempt to mediate between the property holders and the mortgagees might mitigate somewhat the hardships of the land assembly program and, for this very reason, might expedite the job of securing the land. Certainly mortgage holders would realize that in many cases their interest would be better served by taking a cash settlement somewhat less than the face value of their paper than by forcing the housing agency to build elsewhere in the city. In this latter event, not only would the mortgage holders in question not receive any cash payment, but their security might be lessened by the competition of the new development with the old and depreciating properties against which their loans are outstanding. Of course, to take on the added duties of mediator between the property owner and his creditors will be a considerable addition to the responsibilities and worries of the housing agency. These added duties should be weighed against the savings in time and effort in negotiation with the property owners themselves. ${ }^{11}$

${ }^{4}$ This phrase may beg the question.

41 The last sentence of the federal statute discussed supra p. ooo, reads: "The court shall have power to make such orders in respect of encumbrances, liens, rents, taxes, assessments, insurance and other charges, if any, as shall be just and equitable." Probably this would not be taken to mean that the federal courts will combine with the eminent domain action, banliruptcy proceedings or a less formal compromise of a property holder's creditors. One can hope, however, that the court in some cases might suggest, if not order, the sealing down of outstanding debts so that the equity owner would not be completely wiped out by the condemnation proceeding. 


\section{Factual Basis for Land Values}

Underlying most of the difficulties of land assembly is the absence of any factual or quasi-scientific basis for estimating land values in the blighted districts. This is a matter that concerns not only housing agencies but tax assessors, mortgage lenders and all actual or prospective property owners in these districts. If one looks at a use map of a large metropolitan city, he will see quite clearly that one of the largest land uses is low-cost housing. If he looks, however, at a land value map, he will see relatively few, if any, large districts (except on the fringes of the city) that are valued on this use. This is due, of course, to the fact that land owners, aided and abetted by real estate men and mortgage lenders, have continually based their ideas of value on some anticipated or hoped-for use that could support a higher land value. Zoning ordinances in recent years have helped to keep alive much irrational optimism on the future uses of land.

Of course, no one will deny that many slums and blighted districts are within areas the probable future use of which is not residential. Land values in such areas should be high enough to preclude residential construction, and every effort should be made to care for as many as possible of the present occupants in other districts. Certainly, if city and community planning mean anything, they should mean that the housing of people of low income should not be allowed to degenerate into a mere tax-paying use for oncoming commercial, industriai, and high-cost residential uses.

On the other hand, much of the land now valued by its owners at values that can be justified only on the expectancy of a future high-income use will never be so used, and the values that have been built up are, therefore, fictitious. The mere fact that exchanges have taken place at these figures does not establish them as a fair or sound market value. The economic theories of market operations as a guide to economic activity are based on the assumption that buyers and sellers not only are seeking their own pecuniary interest but that they are well-informed on the commodities being exchanged. Many people, including not a few learned courts, have glibly taken over the idea of market value without clearly noting the limitations under which it was promulgated by the major economic thinkers and writers. As to land values in blighted districts, one may say safely that much that passes now as evidence of economic value is the untrustworthy opinion of ignorant people on the future use of the land.

The saddest part of this situation is that apparently no one knows enough about city growth and urban land use to give a firm foundation for appraisal of values in a blighted district. ${ }^{42}$ In the past, when our cities were growing rapidly and

${ }^{2}$ There are, however, degrees of ignorance on these matters. One of the first steps in assembling land, which has not been discussed here because it seems obvious, is to secure an appraisal of the fair cash value of the properties. The appraiser or the members of the appraisal committee should be well acquainted with the arcas in question, should not have a financial interest that might warp their judgment, and should be able to testify effectively, if necessary, in condemnation proceedings. Clearly, selecting them is not an easy job. One of the advantages of a special appraisal committee is that its members may be chosen with 
business and industry were expanding, land values based on high hopes of future intensive use were often justified. Today, however, the high values often remain after these former conditions have changed markedly. Another confusing influence might be called "technological unemployment of land." Skyscrapers and other modern commercial and residential structures make possible high land values for the sites on which they are located. The higher the value from such a use, the greater the area over which it exercises an influence. Quite as clearly, however, the more intensive the use, i.e., the more people and the more business that can be piled upon one parcel of land, the fewer the lots that will be needed as sites for commercial, industrial, and high-rental housing uses.

The failure to realize this general fact and the universal failure to measure land use with any accuracy have created the fundamental problems of land values and, therefore, of land assembly in blighted districts. The solution is not a matter of a few weeks or months, but of an intelligently directed program of study and research over a period of years. The housing program cannot be held back until this research work is done, of course, but when it is done the difficulties of land assembly will be much less formidable.

\section{SUMMARY}

Past experience has shown the inadequacy of trying to better urban housing conditions by passing purely restrictive legislation. City planners, architects and builders with the aid of the PWA could today create healthful, convenient and attractive neighborhoods for people of low income if it were possible to assemble suitable areas of land.

The tools that are needed for a land assembly program are the recognition of low-cost housing as a public purpose for which eminent domain may be exercised and, in most states, a revised procedure for condemnation. Even when these are secured, careful attention must be given to the mechanics of assembling the land needed. The first steps are most important. The land owner whose properties are heavily mortgaged presents a difficult problem. Housing agencies should consider carefully mediating between him and his creditors both in the interest of rapid assembly and of ordinary fair dealing.

Finally, while going ahead on the immediate problems of getting housing developments under way, the members of various public bodies for housing should not overlook the confusion and ignorance that marks nearly all attempts to estimate or assess land value in these districts. It is too late now to wait for a factual basis on which a rational appraisal of values can be made but that basis should be supplied as rapidly as possible.

the different requirements in mind; i.e. some members might be chosen primarily because of their familiarity with the areas, one for his ability to testify convincingly, one primarily because of his prestige among other real estate men and his reputation as a level-headed and broad-minded citizen. The committee should be kept as small as seems consistent with a fair balance of abilities and personal qualifications.

In some cities established or special committees of the real estate boards may be used. In cities in which the boards have little prestige or have been rabidly opposed to low-cost housing developments they should be used only after a careful consideration of other possible arrangements. 